\title{
Shift work of nursing professionals and blood pressure, burnout and common mental disorders*
}

\author{
Trabalho em turnos de profissionais de enfermagem e a pressão \\ arterial, burnout e transtornos mentais comuns \\ Trabajo en turnos de profesionales de enfermería y la presión \\ arterial, burnout y trastornos mentales comunes
}

How to cite this article:

Nascimento JOV, Santos J, Meira KC, Pierin AMG, Souza-Talarico JN. Shift work of nursing professionals and blood pressure, burnout and common mental disorders. Rev Esc Enferm USP. 2019;53:e03443. DOI: http://dx.doi.org/10.1590/S1980-220X2018002103443

Jaqueline Oliveira Valdeviño Nascimento ${ }^{1}$

D Juliano dos Santos ${ }^{1}$

Karina Cardoso Meira ${ }^{1}$

Angela Maria Geraldo Pierin ${ }^{1}$

Juliana Nery Souza-Talarico ${ }^{1}$

* Extracted from the thesis: "Risco cardiovascular e carga alostática em profissionais de enfermagem que atuam em oncologia: variáveis biopsicoemocionais e relacionadas ao trabalho", Escola de Enfermagem, Universidade de São Paulo, 2016.

1 Universidade de São Paulo, Escola de Enfermagem, Departamento de Enfermagem Médico-Cirúrgica, São Paulo, SP, Brazil.

\begin{abstract}
Objective: To analyze the influence of shift work on blood pressure, the presence of burnout and common mental disorders in nursing professionals. Method: A crosssectional study. Burnout was assessed by the Maslach Burnout Inventory, and Common Mental Disorders by the Self-Reporting Questionnaire. Casual blood pressure measurement and Ambulatory Blood Pressure Monitoring (ABPM) were performed. Results: 231 professionals participated. The majority (59.7\%) worked in shifts, and this condition was associated $(\mathrm{p} \leq 0.05)$ with: higher weekly workload; doing the night shift; shorter training and work time at the institution; alcoholism; leisure activity; and alteration in ambulatory blood pressure monitoring of the sleep period. The professionals with common mental disorders and who worked in shifts had lower casual diastolic pressure levels $(p=0.039)$ and higher hypertension prevalence $(p=0.045)$. The presence of emotional exhaustion was associated with normal waking blood pressure and depersonalization with altered sleep blood pressure. Conclusion: Shift work was associated with a higher prevalence of work-related negative factors, inadequate habits and lifestyles, and change in sleep blood pressure.
\end{abstract}

\section{DESCRIPTORS}

Nursing; Shift Work Schedule; Burnout, Profissional; Mental Disorders; Life Style; Hypertension. 


\section{INTRODUCTION}

Shift workers are exposed to risk factors for chronic noncommunicable diseases such as hypertension, overweight/ obesity, hypercholesterolemia and metabolic syndrome, as well as cardiovascular events such as acute myocardial infarction, stroke and coronary artery disease ${ }^{(1)}$.

Shift work is defined as work that is performed intermittently and at different times, without a fixed schedule ${ }^{(2)}$, it is related to the stress characteristic of this condition and the resulting physiological responses, such as activation of the neuroendocrine reaction of stress by the hypothalamicpituitary-adrenal axis and glucocorticoid secretion, and of the autonomic reaction with the release of catecholamines. Prolonged and repeated release of these primary stress mediators with action on different target organs can trigger changes in blood pressure, heart rate, thrombotic and immune response processes, lipid and glucose metabolism, and central nervous system functioning ${ }^{(3)}$, increasing the risk of becoming ill.

High blood pressure is considered the single most important risk factor for the global burden of diseases in the world, accounting for more than nine million deaths in $2010^{(4)}$, and the association between arterial hypertension and cardiovascular disease, being the main cause of morbidity and mortality, has been widely demonstrated ${ }^{(5)}$. In this context, a study with doctors and nurses working in shifts showed a significant increase in blood pressure during the work period and an increase in cardiovascular risk ${ }^{(6)}$. However, it is noteworthy that there are few studies which have evaluated the influence of shift work on blood pressure through 24-hour Ambulatory Blood Pressure Monitoring (ABPM), constituting an important limitation, considering that ABPM enables a more reliable assessment of the blood pressure pattern, including the sleep period. Thus, it can be concluded that analyzing the blood pressure pattern of nurses working in shifts through ABPM is of great value for knowledge construction about the subject, as it will help in shaping future research and guide intervention strategies related to the health of these workers.

Moreover, it is assumed that states of depression, psychiatric disorders and stress may favor developing cardiovascular diseases. From this perspective, Common Mental Disorders (CMD) and Burnout Syndrome (BS) are included ${ }^{(7-8)}$.

CMDs are characterized by signs and symptoms related to the mood state, anxiety and substance abuse, which demonstrates disruption in the normal functioning of the individual $^{(9)}$. In Brazil, CMD prevalence was $35.0 \%{ }^{(10)}$ among nursing workers, and $80.6 \%$ of the cases among those working in intensive care were associated with Burnout Syndrome ${ }^{(11)}$.

Burnout is defined as a multidimensional syndrome, involving three components: emotional exhaustion, depersonalization and low professional achievement, which are associated with work overload of individuals who act directly with people ${ }^{(12)}$. In Brazil, an evaluation performed through the Maslach Burnout Inventory (MBI) showed that this syndrome was present in $4.7 \%$ of nurses in a general hospital ${ }^{(13)}$ and in $55.3 \%$ of nursing professionals in intensive care units ${ }^{(14)}$. There are different ways to define the presence of Burnout Syndrome at the international level, but the prevalence of high levels of emotional exhaustion $(25.0 \%-45.0 \%)^{(15-16)}$, depersonalization $(30.0 \%-42.0 \%)^{(15-16)}$ and low professional achievement $(28.5 \%-45.0 \%)^{(15-16)}$ is high. The great difference in CMD and BS prevalence among these nursing workers may be related to the severity of the patients in the intensive care unit, and consequently to the increase in the nursing team's workload.

At the same time, shift workers are at greater risk for illness due to the higher prevalence of smoking, alterations in sleeping and being awake and inadequate diet, constituting risk factors which may be related to the work characteristics ${ }^{(12)}$, with consequent repercussions on quality of life due to adaptations in daily life for performing work activities ${ }^{(17)}$.

Considering that nursing is mainly composed of women who are often exposed to double working hours, and also that nursing professionals are subject to multiple employment responsibilities due to low pay, and consequently to long working days, it is considered that these professionals may have greater vulnerability to sickness in the context of shift work.

In view of the above, the present study aimed to analyze the influence of shift work on blood pressure, the presence of burnout and common mental disorders in nursing professionals.

\section{METHOD \\ STUDY DESIGN}

This is a cross-sectional study.

\section{SCENARIO}

This study was carried out in a public hospital specialized in the care of cancer patients, in the city of Rio de Janeiro, Brazil.

\section{SeleCtion CRITERIA}

Nursing professionals who assisted in caring for cancer patients in hospitalization units and who had been employed by the institution for at least 1 year were included. Professionals who were on leave $(n=11)$ or pregnant $(n=1)$ were excluded. There was no exclusion for service time in the hospital of less than 1 year, but eight professionals refused to participate in the study, which left 231 who composed the final sample.

\section{SAMPLE DEFINITION}

There were 357 professionals selected out of a total of 574 by means of simple random sampling in order to compose the selected sample $(n=220)$, plus $10 \%(n=22)$ who participated in the pilot study and loss replacement $(n=115)$. The sample size was calculated based on the estimate of arterial hypertension prevalence at $40.0 \%$ from the eligible population of 574 professionals, and thus the final sample consisted of 231 professionals. 


\section{Data collection}

The professionals were characterized through an interview using the author's own instrument, which contained personal identification variables (gender, age, education, race/color, marital status and monthly income), variables related to work (professional category, specialization, working hours/week, number of jobs, and work shift), lifestyle and habits (smoking, alcoholism, physical inactivity, stress and leisure) and personal antecedents (dyslipidemias, arterial hypertension, angina pectoris, diabetes mellitus, acute myocardial infarction, and stroke).

Burnout was evaluated through the Maslach Burnout Inventory (MBI), a self-reporting instrument composed of 22 items distributed in three subscales: emotional exhaustion (9 items), depersonalization (5 items) and low professional achievement ( 8 items). The cut-off points for each of the dimensions were based on the table provided by the instrument manual ${ }^{(18)}$ : emotional exhaustion $(\geq 27)$, depersonalization $(\geq 10)$ and low professional achievement $(\leq 33)$. The presence of burnout was defined based on the cut-off points for the three dimensions, concomitantly. The instrument showed good reliability for all items (Cronbach's alpha $=0.73$ ) and emotional exhaustion (Cronbach's alpha $=0.88)$, depersonalization (Cronbach's alpha $=0.67$ ) and low professional achievement (Cronbach's alpha $=0.73$ ).

Common mental disorders were evaluated by the Self-Reporting Questionnaire (SRQ-20), an instrument validated in Brazil which verifies the presence of common mental disorders and disorders characterized by symptoms such as insomnia, fatigue, irritability, forgetfulness, difficulty in concentrating and somatic complaints. The instrument is composed of 20 dichotomous questions (yes/no), the recommended cut-off points are 6 for men and 8 for women, and it had an internal consistency of 0.80 in the present study ${ }^{(19)}$.

The casual blood pressure measurement was performed three consecutive times with a validated automatic device with a 2-minute interval between the measurements, appropriate cuff to the arm size, in the seated position, following the recommendations of the VII Brazilian Hypertension Guideline ${ }^{(20)}$. Hypertension was characterized with the presence of at least one of the following possibilities: values of the casual measure greater than or equal to $140 \mathrm{mmHg}$ and/or $90 \mathrm{mmHg}$, use of antihypertensive drugs or self-reported hypertension.

Ambulatory Blood Pressure Monitoring (ABPM) was performed for 24 hours during a duty day with a validated device, following the recommendations of the $\mathrm{V}$ Ambulatory Blood Pressure Monitoring Guideline ${ }^{(21)}$. The averages and prevalences of 24-hour hypertension, awake and sleep period were evaluated based on the schedules described in the participants' activity reports. The adopted cut-off points for hypertension for systolic and diastolic pressures respectively, were: $\geq 130 / 80 \mathrm{mmHg}$ in the 24 -hour $\approx$ period; $\geq 135 / 85 \mathrm{mmHg}$ in wakefulness; and $\geq 120 / 70 \mathrm{mmHg}$ in the sleep period.

\section{DATA ANALYSIS AND PROCESSING}

The analysis of the relationships between shift work and the nominal or ordinal variables were done using the Pearson chi-square test, likelihood ratio or Fisher's exact test. The Mann-Whitney U test or Student's T-test was used for continuous variables, according to the normality of the variables under study, while the mean of the last two measurements of the casual blood pressure was used in analyzing the variable blood pressure. The significance level was $5 \%$, and the data were analyzed in the R version 3.2.1 and SPSS v.20.0 statistical programs.

\section{ETHICAL ASPECTS}

The study was approved by the Research Ethics Committee of the Nursing School of the Universidade de São Paulo, under Opinion no. 320.343 of 2013, according to Resolution no. 466/12, of the National Health Council.

Data collection took place between 12/01/2013 and $06 / 30 / 2015$, and the professionals who accepted to participate in the research signed the Free and Informed Consent Form.

\section{RESULTS}

The mean age of professionals was 39.6 years; the majority were female $(82.7 \%)$, non-white race/color $(54.5 \%)$ and lived with companion (70.6\%). In relation to education, the majority had training compatible with residency/ specialization (43.3\%) or technical level (33.7\%), and an average monthly family income of around $\mathrm{R} \$ 9,000$ (BRL). Hypertension prevalence was $35.1 \%$.

There was no statistically significant difference between the professional groups in relation to sociodemographic characteristics (data not shown).

Regarding the characteristics related to the professionals' activity, the category of nursing assistant and technicians of clinical oncology and surgical oncology units was predominant. The majority of the professionals were distributed in the daytime, had an employment contract and worked in a routine of approximately 52 hours a week. The average professional training time was around 16 years, being 8 years in the institution (Table 1).

The professionals who worked in shifts were mostly Nursing Assistants/Technicians, did more night shifts, had a higher weekly workload, graduated more recently, and worked less time at the institution ( $\mathrm{p} \leq 0.05$; Table 1$)$.

Regarding habits and lifestyles, the majority (65.4\%) reported physical inactivity and some type of leisure (69.7\%). A little less than half (44.6\%) were considered stressed, the burnout prevalence was $39.0 \%$, and $57.6 \%$ had common mental disorders (Table 2).

The professionals in this study slept an average of 6.0 hours a day, and the most common comorbidities were dyslipidemia (28.1\%) and arterial hypertension (25.5\%) (Table 2).

The shift workers reported a higher intake of alcoholic beverages (37.0\% vs. $19.4 \%)$ and had some type of leisure (75.4\% vs. 61.3\%) (Table 2 ).

In observing the data in Table 3, altered blood pressure by the casual measure was observed in $13.0 \%$, while $30.0 \%$ by $A B P M$ in the 24 -hour period, $26.0 \%$ by ABPM in the waking period, and $40.4 \%$ by ABPM in the sleep period. 
Table 1 - Sociodemographic and work-related characteristics of nursing professionals working in oncology, according to shift work - Rio de Janeiro, RJ, Brazil, 2015.

\begin{tabular}{|c|c|c|c|c|c|c|c|}
\hline \multirow{3}{*}{$\begin{array}{l}\text { Characteristics } \\
\text { related to work }\end{array}$} & \multicolumn{6}{|c|}{ Shift work } & \multirow{3}{*}{ P-Value } \\
\hline & \multicolumn{2}{|c|}{ Yes } & \multicolumn{2}{|c|}{ No } & \multicolumn{2}{|c|}{ Total } & \\
\hline & $\mathbf{n}$ & $\%$ & $\mathbf{n}$ & $\%$ & $\mathbf{N}$ & $\%$ & \\
\hline \multicolumn{8}{|l|}{ Professional Category } \\
\hline Nurse & 61 & 44.2 & 23 & 24.7 & 84 & 36.4 & \multirow[b]{2}{*}{0.003} \\
\hline $\begin{array}{l}\text { Nursing Assistant/ } \\
\text { Technician }\end{array}$ & 77 & 55.8 & 70 & 75.3 & 147 & 63.6 & \\
\hline \multicolumn{8}{|l|}{ Work unit } \\
\hline Surgical Oncology & 54 & 39.1 & 30 & 32.3 & 84 & 36.4 & \multirow{4}{*}{$0.632^{+}$} \\
\hline Clinical Oncology & 40 & 29.0 & 30 & 32.3 & 70 & 30.3 & \\
\hline $\begin{array}{l}\text { Clinical and Surgical } \\
\text { Oncology }\end{array}$ & 17 & 12.3 & 10 & 10.8 & 27 & 11.7 & \\
\hline Intensive Care Unit & 27 & 19.6 & 23 & 24.7 & 50 & 21.6 & \\
\hline
\end{tabular}

\begin{tabular}{lccccccc}
\hline Work schedule/shift & & & & & & & \\
Day shift & 75 & 54.3 & 51 & 54.8 & 126 & 54.5 & \\
Night shift & 57 & 41.3 & 30 & 32.3 & 87 & 37.7 & $\mathbf{0 . 0 4 1}^{+}$ \\
Part-time work & 6 & 4.3 & 12 & 12.9 & 18 & 7.8 & \\
\hline
\end{tabular}

\begin{tabular}{|c|c|c|c|c|c|c|}
\hline \multicolumn{7}{|c|}{ Weekly working hours } \\
\hline Mean (SD) & \multicolumn{2}{|c|}{$54.2(17.0)$} & \multicolumn{2}{|c|}{$48.7(12.4)$} & $51.9(15.5)$ & $0.016 *$ \\
\hline \multicolumn{7}{|c|}{ Number of employment contracts } \\
\hline Mean (SD) & \multicolumn{2}{|c|}{$1.53(0.60)$} & \multicolumn{2}{|c|}{$1.39(0.51)$} & $1.48(0.57)$ & $0.079 *$ \\
\hline 1 & 72 & 52.2 & 58 & 62.4 & $\begin{array}{ll}130 & 56.3\end{array}$ & \\
\hline$\geq 2$ & 66 & 47.8 & 35 & 37.6 & 10143.7 & \\
\hline
\end{tabular}

Time since graduation (in years)

\begin{tabular}{|c|c|c|c|c|c|c|c|}
\hline Mean (SD) & \multicolumn{2}{|c|}{$15.4(7.9)$} & \multicolumn{2}{|c|}{$17.6(7.6)$} & \multicolumn{2}{|c|}{$16.3(7.8)$} & 0.019* \\
\hline \multicolumn{8}{|c|}{ Institutional working time } \\
\hline Mean (SD) & \multicolumn{2}{|c|}{$7.9(7.2)$} & \multicolumn{2}{|c|}{$9.6(7.8)$} & \multicolumn{2}{|c|}{$8.6(7.5)$} & 0.039 \\
\hline \multicolumn{8}{|l|}{ Working tired } \\
\hline Frequently & 53 & 38.4 & 35 & 37.6 & 88 & 38.1 & \\
\hline Sometimes & 72 & 52.2 & 53 & 57.0 & 125 & 54.1 & $0.480^{+}$ \\
\hline Rarely/Never & 13 & 9.4 & 5 & 5.4 & 18 & 7.8 & \\
\hline
\end{tabular}

Concentration is decreased during the shift

\begin{tabular}{lccccccc} 
Frequently & 18 & 13.0 & 11 & 11.8 & 29 & 12.6 & \\
Sometimes & 63 & 45.7 & 52 & 55.9 & 115 & 49.8 & $0.293^{+}$ \\
Rarely/Never & 57 & 41.3 & 30 & 32.3 & 87 & 37.7 & \\
\hline
\end{tabular}

*Mann-Whitney U test; +Likelihood ratio.

Note: $(n=231)$.

The shift workers presented greater changes in blood pressure during sleep compared to those who did not work in shifts $(45.9 \%$ vs. $31.8 \%, \mathrm{p}=0.036)$. No statistically significant differences were observed in the other blood pressure comparisons.

Among the 138 professionals working in shifts, there was a lower prevalence of hypertension among those with common mental disorders $(26.2 \%$ vs. $42.6 \%, \mathrm{p}=0.045)$, as well as higher mean casual diastolic blood pressure $(\mathrm{p}=0.039$, Table 4$)$.

In shift workers, there was an association between less emotional exhaustion and altered blood pressure levels in $\mathrm{ABPM}$ during the waking period $[26.0(\mathrm{SD}=7.6)$ vs. 29.9 $(\mathrm{SD}=7.6)$ points $]$ and greater depersonalization and altered blood pressure levels in ABPM of the sleep period [12.2 $(\mathrm{SD}=4.6)$ vs. $10.7(\mathrm{SD}=4.3)$ points] (Table 5).

Table 2 - Life habits, anthropometric variables and personal antecedents according to shift work - Rio de Janeiro, RJ, Brazil, 2015.

\begin{tabular}{|c|c|c|c|c|c|c|c|}
\hline \multirow{3}{*}{ Habits and lifestyle } & \multicolumn{6}{|c|}{ Shift work } & \multirow{3}{*}{ P-Value } \\
\hline & \multicolumn{2}{|c|}{ Yes } & \multicolumn{2}{|c|}{ No } & \multicolumn{2}{|c|}{ Total } & \\
\hline & $\mathbf{n}$ & $\%$ & $\mathbf{n}$ & $\%$ & $\mathbf{n}$ & $\%$ & \\
\hline Smoker & 9 & 6.5 & 5 & 5.4 & 14 & 6.1 & 0.720 \\
\hline Alcoholism & 51 & 37.0 & 18 & 19.4 & 69 & 29.8 & 0.004 \\
\hline Physical inactivity & 93 & 67.4 & 58 & 62.4 & 151 & 65.4 & 0.431 \\
\hline Stress & 62 & 44.9 & 41 & 44.1 & 103 & 44.6 & 0.900 \\
\hline Burnout & 56 & 40.6 & 34 & 36.6 & 90 & 39.0 & 0.539 \\
\hline $\begin{array}{l}\text { Emotional exhaustion: } \\
\text { Mean (SD) }\end{array}$ & \multicolumn{2}{|c|}{$28.8(7.8)$} & \multicolumn{2}{|c|}{$28.3(7.8)$} & \multicolumn{2}{|c|}{$28.6(7.8)$} & 0.617 \\
\hline $\begin{array}{l}\text { Depersonalization: } \\
\text { Mean (SD) }\end{array}$ & \multicolumn{2}{|c|}{$11.4(4.4)$} & \multicolumn{2}{|c|}{$11.3(4.0)$} & \multicolumn{2}{|c|}{$11.4(4.3)$} & 0.986 \\
\hline $\begin{array}{l}\text { Low professional } \\
\text { achievement: Mean } \\
\text { (SD) }\end{array}$ & \multicolumn{2}{|c|}{$29.6(5.4)$} & \multicolumn{2}{|c|}{$29.9(5.6)$} & \multicolumn{2}{|c|}{$29.7(5.5)$} & 0.429 \\
\hline $\begin{array}{l}\text { Common Mental } \\
\text { Disorders }\end{array}$ & 84 & 60.9 & 49 & 52.7 & 133 & 57.6 & 0.217 \\
\hline Does leisure activity & 104 & 75.4 & 57 & 61.3 & 161 & 69.7 & 0.022 \\
\hline Sleep hours Mean (SD) & \multicolumn{2}{|c|}{$6.3(1.5)$} & \multicolumn{2}{|c|}{$6.2(1.6)$} & \multicolumn{2}{|c|}{$6.3(1.5)$} & $0.669^{*}$ \\
\hline \multicolumn{8}{|l|}{ Comorbidities } \\
\hline Dyslipidemias & 33 & 23.9 & 32 & 34.4 & 65 & 28.1 & 0.082 \\
\hline Arterial Hypertension & 34 & 24.6 & 25 & 26.9 & 59 & 25.5 & 0.701 \\
\hline Angina pectoris & 13 & 9.4 & 5 & 5.4 & 18 & 7.8 & 0.261 \\
\hline Diabetes mellitus & 7 & 5.1 & 7 & 7.5 & 14 & 6.1 & 0.443 \\
\hline $\begin{array}{l}\text { Acute myocardial } \\
\text { infarction }\end{array}$ & 2 & 1.4 & 0 & 0.0 & 2 & 0.9 & $0.517^{\ddagger}$ \\
\hline Stroke & 0 & 0.0 & 1 & 1.1 & 1 & 0.4 & $0.403^{\ddagger}$ \\
\hline
\end{tabular}

*Mann-Whitney U Test; +Likelihoodw ratio; \#Fisher's Exact Test; $\S$ Two-tailed Student's t-test.

Note: $(n=231)$. 
Table 3 - Characterization of the professionals in relation to blood pressure levels $(\mathrm{mmHg})$ by casual measure and ABPM, according to shift work - Rio de Janeiro, RJ, Brazil, 2015.

\begin{tabular}{|c|c|c|c|c|c|c|c|}
\hline \multirow{3}{*}{ Blood pressure } & \multicolumn{6}{|c|}{ Shift work } & \multirow{3}{*}{ P-Value } \\
\hline & \multicolumn{2}{|c|}{ Yes } & \multicolumn{2}{|c|}{ No } & \multicolumn{2}{|c|}{ Total } & \\
\hline & $\mathbf{n}$ & $\%$ & $\mathbf{n}$ & $\%$ & $\mathbf{n}$ & $\%$ & \\
\hline \multicolumn{8}{|l|}{ Casual } \\
\hline Altered casual blood pressure & 15 & 10.9 & 15 & 16.1 & 30 & 13.0 & 0.244 \\
\hline Systolic: Mean (SD) & \multicolumn{2}{|c|}{$118.8(15.1)$} & \multicolumn{2}{|c|}{$121.4(17.2)$} & \multicolumn{2}{|c|}{$119.4(16.0)$} & $0.275^{*}$ \\
\hline Diastolic: Mean (SD) & \multicolumn{2}{|c|}{$76.6(11.0)$} & \multicolumn{2}{|c|}{$82.4(44.1)$} & \multicolumn{2}{|c|}{$78.9(29.3)$} & $0.323^{*}$ \\
\hline \multicolumn{8}{|l|}{ ABPM 24 hous } \\
\hline Altered blood pressure & 43 & 31.9 & 24 & 27.3 & 67 & 30.0 & 0.466 \\
\hline Systolic: Mean (SD) & \multicolumn{2}{|c|}{$119.2(12.1)$} & \multicolumn{2}{|c|}{$116.3(11.0)$} & \multicolumn{2}{|c|}{$118.1(11.7)$} & $0.123^{*}$ \\
\hline Diastolic: Mean (SD) & \multicolumn{2}{|c|}{$75.4(8.8)$} & \multicolumn{2}{|c|}{$73.9(8.8)$} & \multicolumn{2}{|c|}{$74.8(8.8)$} & $0.206^{*}$ \\
\hline \multicolumn{8}{|l|}{ Awake ABPM } \\
\hline Altered blood pressure & 39 & 28.9 & 19 & 21.6 & 58 & 26 & 0.225 \\
\hline Systolic: Mean (SD) & \multicolumn{2}{|c|}{$122.5(12.4)$} & \multicolumn{2}{|c|}{$120.1(11.2)$} & \multicolumn{2}{|c|}{$121.5(12.0)$} & $0.206^{*}$ \\
\hline Diastolic: Mean (SD) & \multicolumn{2}{|c|}{$78.9(9.1)$} & \multicolumn{2}{|c|}{$77.8(8.2)$} & \multicolumn{2}{|c|}{$78.5(8.8)$} & $0.426^{*}$ \\
\hline \multicolumn{8}{|l|}{ Sleep ABPM } \\
\hline Altered blood pressure & 62 & 45.9 & 28 & 31.8 & 90 & 40.4 & 0.036 \\
\hline Systolic: Mean (SD) & \multicolumn{2}{|c|}{$111.7(13.7)$} & \multicolumn{2}{|c|}{$108.6(13.0)$} & \multicolumn{2}{|c|}{$110.5(13.5)$} & $0.072 *$ \\
\hline Diastolic: Mean (SD) & \multicolumn{2}{|c|}{$68.1(10.9)$} & \multicolumn{2}{|c|}{$66.1(11.2)$} & \multicolumn{2}{|c|}{$67.3(11.0)$} & $0.108^{*}$ \\
\hline
\end{tabular}

*Mann-Whitney U Test; ABPM: Ambulatory Blood Pressure Monitoring.

Note: $(\mathrm{n}=231)$.

Table 4 - Characterization of the professionals who worked shifts in relation to blood pressure levels $(\mathrm{mmHg})$ by casual measure and ABPM according to burnout and common mental disorders - Rio de Janeiro, RJ, Brazil, 2015.

\begin{tabular}{|c|c|c|c|c|c|c|c|c|c|c|}
\hline \multirow{4}{*}{ Blood Pressure } & \multicolumn{9}{|c|}{ Shift work $(n=138)$} & \multirow{4}{*}{ P-Value } \\
\hline & \multicolumn{4}{|c|}{ Burnout } & \multirow{3}{*}{ P-Value } & \multicolumn{4}{|c|}{ Common mental disorders } & \\
\hline & \multicolumn{2}{|c|}{ Yes } & \multicolumn{2}{|c|}{ No } & & \multicolumn{2}{|c|}{ Yes } & \multicolumn{2}{|c|}{ No } & \\
\hline & $\mathbf{n}$ & $\%$ & $\mathbf{n}$ & $\%$ & & $\mathbf{n}$ & $\%$ & $\mathbf{n}$ & $\%$ & \\
\hline \multicolumn{11}{|l|}{ Casual measurement } \\
\hline Altered casual blood pressure & 7 & 12.5 & 8 & 9.8 & 0.611 & 10 & 11.9 & 5 & 9.3 & 0.626 \\
\hline Systolic: Mean (SD) & \multicolumn{2}{|c|}{$119.9(15.5)$} & \multicolumn{2}{|c|}{$118.0(14.9)$} & $0.557^{*}$ & \multicolumn{2}{|c|}{$117.4(15.8)$} & \multicolumn{2}{|c|}{$121.0(13.9)$} & $0.062^{*}$ \\
\hline Diastolic: Mean (SD) & \multicolumn{2}{|c|}{$76.1(10.9)$} & \multicolumn{2}{|c|}{$76.9(11.1)$} & $0.671^{*}$ & \multicolumn{2}{|c|}{$75.2(11.4)$} & \multicolumn{2}{|c|}{$78.7(10.1)$} & 0.039* \\
\hline Hypertension & 16 & 28.6 & 29 & 35.4 & 0.403 & 22 & 26.2 & 23 & 42.6 & 0.045 \\
\hline \multicolumn{11}{|l|}{ ABPM 24 hours } \\
\hline Altered blood pressure & 16 & 29.6 & 27 & 33.3 & 0.651 & 25 & 30.9 & 18 & 33.3 & 0.763 \\
\hline Systolic: Mean (SD) & \multicolumn{2}{|c|}{$119.1(11.7)$} & \multicolumn{2}{|c|}{$119.2(12.4)$} & $0.984^{*}$ & \multicolumn{2}{|c|}{$119.1(11.6)$} & \multicolumn{2}{|c|}{$119.4(12.9)$} & $0.793^{*}$ \\
\hline Diastolic: Mean (SD) & \multicolumn{2}{|c|}{$75.5(8.4)$} & \multicolumn{2}{|c|}{$75.4(9.0)$} & $0.943^{*}$ & \multicolumn{2}{|c|}{$75.1(8.2)$} & \multicolumn{2}{|c|}{$75.9(9.6)$} & $0.829^{*}$ \\
\hline \multicolumn{11}{|l|}{ Awake ABPM } \\
\hline Altered blood pressure & 15 & 27.8 & 24 & 29.6 & 0.816 & 22 & 27.2 & 17 & 31.5 & 0.587 \\
\hline Systolic: Mean (SD) & \multicolumn{2}{|c|}{$122.2(12.7)$} & \multicolumn{2}{|c|}{$122.6(12.3)$} & $0.902 *$ & \multicolumn{2}{|c|}{$122.6(12.4)$} & \multicolumn{2}{|c|}{$122.3(12.5)$} & $0.678^{*}$ \\
\hline Diastolic: Mean (SD) & & & & & $0.986^{*}$ & & & & & $0.886^{*}$ \\
\hline Sleep ABPM & & & & & & & & & & \\
\hline Altered blood pressure & 27 & 50.0 & 35 & 43.2 & 0.438 & 37 & 45.7 & 25 & 46.3 & 0.944 \\
\hline Systolic: Mean (SD) & 112 & 2.6) & 111 & 4.4) & $0.487^{*}$ & & 2.6) & & 5.3) & $0.770^{*}$ \\
\hline Diastolic: Mean (SD) & & $0.3)$ & & 1.2) & $0.270^{*}$ & & & & 2.3) & $0.914^{*}$ \\
\hline
\end{tabular}

ABPM: Ambulatory Blood Pressure Monitoring; * Mann-Whitney U Test.

Note: $(\mathrm{n}=138)$. 
Table 5 - Relationship between blood pressure and burnout subscales among nursing professionals working in shifts - Rio de Janeiro, RJ, Brazil, 2015.

\begin{tabular}{|c|c|c|c|c|c|c|}
\hline & \multicolumn{2}{|c|}{ Emotional exhaustion } & \multicolumn{2}{|c|}{ Depersonalization } & \multicolumn{2}{|c|}{ Low professional achievement } \\
\hline & Mean (SD) & P-Value & Mean (SD) & P-Value & Mean (SD) & P-Value* \\
\hline \multicolumn{7}{|c|}{ Arterial Hypertension } \\
\hline Yes & $28.1(6.8)$ & \multirow{2}{*}{0.530} & $11.1(4.0)$ & \multirow{2}{*}{0.670} & $30.1(6.0)$ & \multirow{2}{*}{0.515} \\
\hline No & $29.2(8.2)$ & & $11.6(4.7)$ & & $29.3(5.1)$ & \\
\hline \multicolumn{7}{|c|}{ ABPM 24 hours } \\
\hline Altered & $27.1(8.4)$ & \multirow{2}{*}{0.085} & $12.3(4.2)$ & \multirow{2}{*}{0.073} & $29.7(5.7)$ & \multirow{2}{*}{0.979} \\
\hline Normal & $29.5(7.4)$ & & $11.0(4.6)$ & & $29.5(5.3)$ & \\
\hline \multicolumn{7}{|l|}{ Awake } \\
\hline Altered & $26.0(7.6)$ & \multirow{2}{*}{0.012} & $12.2(4.0)$ & \multirow{2}{*}{0.113} & $29.5(5.7)$ & \multirow{2}{*}{0.754} \\
\hline Normal & $29.9(7.6)$ & & $11.1(4.7)$ & & $29.6(5.3)$ & \\
\hline \multicolumn{7}{|l|}{ Sleep } \\
\hline Altered & $28.1(8.2)$ & \multirow{2}{*}{0.414} & $12.2(4.6)$ & \multirow{2}{*}{0.036} & $29.2(6.2)$ & \multirow{2}{*}{0.439} \\
\hline Normal & $29.3(7.4)$ & & $10.7(4.3)$ & & $29.9(4.7)$ & \\
\hline
\end{tabular}

ABPM: Ambulatory Blood Pressure Monitoring; *Mann-Whitney U Test.

\section{DISCUSSION}

The present study showed statistically significant differences in variables related to work, life habits and altered blood pressure during the sleep period among professionals working in alternating shifts in relation to those who did not work shifts. Also, the professionals who worked in alternating shifts showed differences between the pressure levels and presented emotional exhaustion, depersonalization and CMD.

The greatest change in blood pressure during the sleep period among those who worked in shifts was a particularly relevant finding, as blood pressure during the sleep period is expected to decrease, called a drop. The absence of a drop and the intensity in which it occurs are related to autonomic dysfunction, sleep apnea, nocturnal volume overload, increased mortality, development of lesions in target organs such as left ventricular hypertrophy, reduced myocardial diastolic function, increased prevalence of diabetic retinopathy and decreased glucose tolerance ${ }^{(22)}$.

In this context, a systematic review with a recent metaanalysis involving Brazilian, European and Japanese cohorts considering the reference measurement and parameters provided by ABPM, showed that nocturnal hypertension was the only predictor for cardiovascular events such as acute myocardial infarction or stroke ${ }^{(23)}$. Thus, although the mean blood pressure levels observed at both random and at different periods of ABPM were within the normal range, the hypertension observed during sleep, especially among shift workers, suggests that they are exposed to greater cardiovascular risk ${ }^{(23)}$.

Regarding the work schedule, although the majority of those working in shifts had daytime shifts as a fixed schedule, it was noted that the prevalence of fixed night-time shifts among those working in alternate shifts was significant, and these work regimes (shifts/night) are associated with sleep deficiency, loss of quality, duration and/or perceived sufficiency, high cardiovascular risk, and correlation with coronary heart disease ${ }^{(1,5)}$. It is considered that many nursing professionals opt for the night shift work due to the additional payment for the shift, and for facilitating domestic tasks and daily life, since the majority of these workers are women, mostly being responsible for domestic activities and childcare beyond work ${ }^{(17)}$.

It was also observed that the professionals who worked in shifts had shorter working in the institution, more recently graduated and a higher weekly workload, and these findings can be related to the fact that professionals with shorter institutional working time and vocational training are usually younger and more willing or able to work in shifts. Still, those with shorter training time are generally the ones with their most "exploited" performance potentials. This can be a challenge, but at the same time it is early exposure to overload, and consequently to the risk of becoming ill.

It was found that the average weekly working hours of the present study participants (52 hours/week) was above the recommended level ${ }^{(24)}$, even among shift workers, which may negatively influence rest time and leisure, work capacity, ergonomic, biological and physical risks ${ }^{(2)}$, in addition to acting as an associated factor to cardiovascular diseases ${ }^{(25)}$.

In relation to life habits, the differences between the groups were greater alcoholism and practicing leisure activity. Adopted lifestyles such as an increased intake of alcoholic beverages can be associated with the onset of illnesses, as well as being a coping strategy or inadequate coping of work-related stress situations, which has increased among young adults (age group from 20 to 39 years) and in those with higher education ${ }^{(26)}$. This hypothesis is reinforced by the fact that practicing leisure activities was greater among those who worked in shifts, justifying the need of these professionals to use coping strategies for the stress inherent to this condition. However, among the professionals who mentioned leisure activities, physical activity was an interesting finding, given that people who practice it have a lower risk of developing morbidities such as cardiovascular diseases, diabetes, obesity, depression and anxiety ${ }^{(27)}$, and shift work is associated with an increased risk for being overweight/ obese $^{(28)}$. On the other hand, people who are insufficiently active, like most of the professionals studied, present a higher risk for all causes of mortality ${ }^{(29)}$.

The shift work condition did not influence the prevalence of Burnout Syndrome (39.0\%) or common mental disorders 
(57.6\%); however, the proportions observed in the present study were higher than those observed among nursing professionals in generally large hospitals $\left(4.7 \%{ }^{(13)}\right.$ and $\left.35.0 \%{ }^{(10)}\right)$.

The observed high prevalence of burnout and common mental disorders can directly and indirectly interfere in the individual, family and social functioning of the affected individual. It is important to note that both the professional and the patient's safety may be impaired, since professionals affected by Burnout Syndrome feel exhausted, frequently ill, suffer from insomnia, digestive ulcer, headaches, problems related to blood pressure, muscle tension and chronic fatigue ${ }^{(12)}$.

Differently from the observed among hypertensive patients with altered blood pressure levels during work activities in which Burnout Syndrome prevalence was higher (59.0\%) than that observed in hypertensive patients without work hypertension (36.0\%) and in healthy individuals $(9.0 \%)^{(7)}$, there was no association between hypertension and Burnout Syndrome in the present study. However, there was an association between less emotional exhaustion and altered blood pressure levels in ABPM during the waking period and greater depersonalization with altered blood pressure levels in ABPM during the sleep period, showing that the professionals who presented depersonalization were more subject to nocturnal hypertension, as well as a relationship between psychoemotional variables and higher cardiovascular risk. In this sense, the presence of CMD was also associated with a higher prevalence of arterial hypertension, as was observed in the study with data from the global mental health survey ${ }^{(8)}$.

The associations observed between the studied psychoemotional variables and arterial hypertension may be related to neuroendocrine alterations or to behaviors that may expose individuals to comorbidities such as arterial hypertension ${ }^{(7-8)}$.

There was also a high prevalence of reported stress (44.6\%), which may be associated with insufficient time for rest between working hours, for leisure activities and for selfcare, with consequent impairment in the quality of life of these professionals, given that there is a correlation between stress and poor sleep quality ${ }^{(30)}$. It is also important to note that stress and burnout are related constructs.

The present study was limited to analyzing the characteristics of the professionals in a short time, which is an inherent characteristic to cross-sectional studies, in which the concomitant evaluation of the risk factors and the outcomes do not allow for establishing cause and effect relationships. However, it is emphasized that the sample was probabilistic, which controls the selection bias and ensures that all professionals have the same probability of being part of the study. In addition, ABPM was used, reducing the influence of the observer and the environment on the evaluation of the blood pressure levels of the individuals, thus controlling the information bias.

The study enabled learning the variables that can be contemplated in intervention programs for nursing professionals who work in this institution, with a view to reducing the exposure of those who work in shifts to cardiovascular risk factors. From the results found, it is also possible to identify professionals with different risk intensities for illness, thereby allowing individualized and follow-up interventions with health promotion actions. These actions constitute important tools for human resources and worker health management, contributing to advance nursing.

\section{CONCLUSION}

Nursing workers who worked in shifts had a higher prevalence of negative factors related to work, inadequate habits and lifestyles, as well as changes in sleep blood pressure when compared to workers who were not exposed to this work schedule. From the findings, it is considered necessary to follow and monitor the professionals who presented risk factors, as well as all others exposed to shift work. It is also necessary to stimulate and promote prevention strategies related to habits and lifestyles, especially regarding physical inactivity and alcohol consumption, aiming to modify the profile of morbidity and modifiable risk factors related to chronic non-communicable diseases in the studied population.

\section{RESUMO}

Objetivo: Analisar a influência do trabalho em turnos na pressão arterial, na presença de burnout e transtornos mentais comuns em profissionais de enfermagem. Método: Estudo transversal. O burnout foi avaliado pelo Maslach Burnout Inventory, e os Transtornos Mentais Comuns, pelo Self Reporting Questionnaire. Realizaram-se a medida casual da pressão e a Monitorização Ambulatorial da Pressão Arterial. Resultados: Participaram 231 profissionais. A maioria (59,7\%) trabalhava em turnos, e essa condição associou-se $(\mathrm{p} \leq 0,05)$ com: maior carga de trabalho semanal; fazer plantão noturno; menor tempo de formado e de trabalho na instituição; etilismo; atividade de lazer; e alteração na monitorização ambulatorial da pressão arterial do período do sono. Os profissionais com transtornos mentais comuns e que trabalhavam em turnos apresentaram menores níveis de pressão casual diastólica $(\mathrm{p}=0,039)$ e maior prevalência de hipertensão $(\mathrm{p}=0,045)$. A presença de exaustão emocional associou-se com pressão arterial de vigília normal e despersonalização com pressão arterial de sono alterada. Conclusão: $\mathrm{O}$ trabalho em turnos associou-se à maior prevalência de fatores negativos relacionados ao trabalho, hábitos e estilos de vida inadequados e alteração da pressão no período de sono.

\section{DESCRITORES}

Enfermagem; Trabalho em Turnos; Esgotamento Profissional; Transtornos Mentais; Estilo de Vida; Hipertensão.

\section{RESUMEN}

Objetivo: Analizar la influencia del trabajo en turnos en la presión arterial, presencia de burnout y trastornos mentales comunes en profesionales enfermeros. Método: Estudio transversal. El burnout fue evaluado por el Maslach Burnout Inventory y los Trastornos Mentales Comunes, por el Self Reporting Questionnaire. Se realizaron la medida casual de la presión y el Monitoreo Ambulatorio de la Presión Arterial. Resultados: Participaron 231 profesionales. La mayoría (59,7\%) trabajaba en turnos, y dicha condición se asoció $(\mathrm{p} \leq 0,05)$ con: mayor carga de trabajo semanal; hacer turno nocturno; menor tiempo de licenciado y de trabajo en el 
centro; etilismo; actividad de ocio; y modificación en el monitoreo ambulatorio de la presión arterial del período del sueño. Los profesionales con trastornos mentales comunes y que trabajaban en turnos presentaron menores niveles de presión casual diastólica $(p=0,039)$ y mayor prevalencia de hipertensión $(p=0,045)$. La presencia de agotamiento emotivo se asoció con presión arterial de vigilia normal y despersonalización con presión arterial de sueño modificado. Conclusión: El trabajo en turnos se asoció con la mayor prevalencia de factores negativos relacionados con el trabajo, hábitos y estilo de vida inadecuados y modificación de la presión en el período de sueño.

\section{DESCRIPTORES}

Enfermería; Horario de Trabajo por Turnos; Agotamiento Profesional; Trastornos Mentales; Estilo de Vida; Hipertensión.

\section{REFERENCES}

1. Vetter C, Devore EE, Wegrzyn LR, Massa J, Speizer FE, Kawachi I, et al. Association between rotating night shift work and risk of coronary heart disease among women. JAMA. 2016;315(16):1726-34. DOI: https://doi.org/ 10.1001/jama.2016.4454

2. Wright KP Jr, Bogan RK, Wyatt JK. Shift work and the assessment and management of shift work disorder (SWD). Sleep Med Rev. 2013;17(1):41-54. DOI: https://doi.org/10.1016/j.smrv.2012.02.002

3. Vicente-Herreroa MT, Alberichb JIT, García LC, Gómez JI, Iñiguez de la Torre MVR, García MJT, et al. Night shift work and occupational health. Rev Esp Med Leg. 2016;42(4):142-54. DOI: https://doi.org/10.1016/j.remle.2016.11.001

4. Lim SS, Vos T, Flaxman AD, Danaei G, Shibuya K, Adair-Rohani H, et al. A comparative risk assessment of burden of disease and injury attributable to 67 risk factors and risk factor clusters in 21 regions, 1990-2010: a systematic analysis for the Global Burden of Disease Study 2010. Lancet. 2012;380(9859):2224-60. DOI: https://doi.org/10.1016/S0140-6736(12)61766-8

5. Roth GA, Forouzanfar MH, Moran AE, Barber R, Nguyen G, Feigin VL et al. Demographic and epidemiologic drivers of global cardiovascular mortality. N Engl J Med. 2015;372:1333-41. DOI: http://dx.doi.org/10.1056/NEJMoa1406656

6. Cavagioni LC, Pierin AMG. Cardiovascular risk among health professionals working in pre-hospital care services. Rev Esc Enferm USP [Internet]. 2012 [cited 2016 Feb 17];46(2):395-403. Available from: http://www.scielo.br/scielo.php?script=sci_arttext\&pid=S0080$62342012000200018 \& \operatorname{lng}=\mathrm{en} \& \mathrm{nrm}=\mathrm{iso} \& \operatorname{lng}=\mathrm{en}$

7. Zinchenko YP, Pervichko El, Ostroumova OD. Burnout syndrome in patients with workplace hypertension. Rational Pharmacother Cardiol. 2016;12(6):675-80. DOI: http://dx.doi.org/10.20996/1819-6446-2016-12-6-675-680

8. Stein DJ, Aguilar-Gaxiola S, Alonso J, Bruffaerts R, Jonge P, Liu Z, et al. Associations between mental disorders and subsequent onset of hypertension. Gen Hosp Psychiatry. 2014;36(2):142-9. DOI: http://dx.doi.org/10.1016/j.genhosppsych.2013.11.002

9. Steel Z, Marnane C, Iranpour C, Chey T, Jackson JW, Patel V, et al. The global prevalence of common mental disorders: a systematic review and meta-analysis 1980-2013, Int J Epidemiol. 2014;43(2):476-93. DOI: http://dx.doi.org/10.1093/ije/dyu038

10. Rodrigues EP, Rodrigues US, Oliveira LMM, Laudano RCS, Sobrinho CLN. Prevalência de transtornos mentais comuns em trabalhadores de enfermagem em um hospital da Bahia. Rev Bras Enferm [Internet]. 2014 [citado 2016 maio 5]; 67(2):296-301. Disponível em: http://www.scielo.br/scielo.php?script=sci_arttext\&pid=S0034-71672014000200296

11. Diniz TB, Silva-Costa A, Griep RH, Rotenberg L. Minor psychiatric disorders among nursing workers-is there an association with current or former night work? Work [Internet]. 2012;41 Suppl 1:2887-92. DOI: http://dx.doi.org/10.3233/WOR-2012-0539-2887.

12. Maslach C, Jackson SE. The measurement of experienced Burnout. J. Sococcup Behav. 1981;2(1):99-113. DOI: http://dx.doi.org/10.1002/ job.4030020205

13. Galindo RH, Feliciano KVO, Lima RAS, Souza AI. Burnout Syndrome among General Hospital Nurses in Recife. Rev Esc Enferm USP [Internet]. 2012 [cited 2016 Jan 11]; 46(2):420-7. Available from: http://www.scielo.br/scielo.php?script=sci_arttext\&pid=S0080$62342012000200021 \& \operatorname{lng}=\mathrm{en} \& \mathrm{nrm}=\mathrm{iso} \& \operatorname{lng}=\mathrm{en}$

14. Silva JL, Soares RS, Costa FS, Ramos DS, Lima FB, Teixeira LR. Psychosocial factors and prevalence of burnout syndrome among nursing workers in intensive care units. Rev Bras Ter Intensiva [Internet]. 2015 [cited 2016 Jul 4]; 27(2):125-33. Available from: http://www.scielo.br/ scielo.php?script=sci_arttext\&pid=S0103-507X2015000200125\&lng=en\&nrm=iso\&tlng=en

15. Cañadas-De la Fuente GA, Vargas C, San Luis C, García I, Cañadas GR, De la Fuente El. Risk factors and prevalence of burnout syndrome in the nursing profession. Int J Nurs Stud. 2015;52(1):240-9. DOI: http://dx.doi.org/10.1016/j.ijnurstu.2014.07.001

16. Al-Turki HA, Al-Turki RA, Al-Dardas HA, Al-Gazal MR, Al-Maghrabi GH, Al-Enizi NH, et al. Burnout syndrome among multinational nurses working in Saudi Arabia. Ann Afr Med. 2010;9(4):226-9. DOI: http://dx.doi.org/10.4103/1596-3519.70960

17. Palhares VC, Corrente JE, Matsubara BB. Association between sleep quality and quality of life in nursing professionals working rotating shifts. Rev Saúde Pública [Internet]. 2014 [cited 2016 Apr 1];48(4):594-601. Available from: http://www.scielo.br/scielo.php?script=sci_ar ttext\&pid=S0034-89102014000400594

18. Maslach C, Jackson S, Leiter M. The Maslach Burnout Inventory manual. In: Zalaquett CP, Wood RJ, editors. Evaluating stress: a book of resources. New York: Scarecrow; c1997.

19. Mari JJ, Williams P. A validity study of a psychiatric screening questionnaire (SRQ-20) in primary care in the city of Sao Paulo. Br J Psychiatry. 1986;148(1):23-6. DOI: http://dx.doi.org/10.1192/bjp.148.1.23

20. Malachias MVB, Souza WKSB, Plavnik FL, Rodrigues CIS, Brandão AA, Neves MFT, et al. $7^{\text {a }}$ Diretriz Brasileira de Hipertensão Arterial. Arq Bras Cardiol [Internet]. 2016 [citado 2016 dez. 22]; 107(3Supl.3):1-83. Disponível em: http://www.scielo.br/pdf/abc/v107n3s3/0066782X-abc-107-03-s3-0049.pdf. 
21. Sociedade Brasileira de Cardiologia. V Diretrizes Brasileiras de Monitorização ambulatorial da pressão arterial (MAPA V) e III Diretriz Brasileiras de Monitorização Residencial da pressão arterial (MRPA III). Arq Bras Cardiol [Internet]. 2011 [citado 2016 dez. 22]; 97(3Supl.3):1-24. Disponível em: http://publicacoes.cardiol.br/consenso/2011/diretriz_mapa_mrpa.pdf

22. Hermida RC, Ayala DE, Mojón A, Smolensky MH, Portaluppi F, Fernández JR. Sleep-time ambulatory blood pressure as a novel therapeutic target for cardiovascular risk reduction. J Hum Hypertens. 2014;28(10):567-74. DOI: http://dx.doi.org/10.1038/jhh.2014.1

23. Roush G, Fagard R, Salles G, Pierdomenico S, Reboldi G, Verdecchia P, et al. Prognostic impact of clinic, daytime, and night time systolic blood pressure in 9 cohorts of 13,843 patients with hypertension: systematic review and meta-analysis. J Am Soc Hypertens. 2014;8(4 Suppl):e59. DOI: http://dx.doi.org/10.1097/HJH.0000000000000355

24. Brasil. Decreto-Lei n. 5.452, de $1^{\circ}$ de maio de 1943. Aprova a Consolidação das Leis do Trabalho. Diário Oficial [dos] Estados Unidos do Brasil, Poder Executivo, Rio de Janeiro, DF, 9 ago. 1943. Secção 1, p. 11937-11984.

25. Conway SH, Pompeii LA, Roberts RE, Follis JL, Gimeno D. Dose-response relation between work hours and cardiovascular disease risk. J Occup Environ Med. 2016;58(3):221-6. DOI: http://dx.doi.org/10.1097/JOM.0000000000000654

26. Garcia LP, Freitas LRS. Heavy drinking in Brazil: results from the 2013 National Health Survey. Epidemiol Serv Saúde [Internet]. 2015 [cited 2017 May 25];24(2):227-37. Available from: http://www.scielo.br/scielo.php?script=sci_arttext\&pid=S2237-96222015000200227\&lng= en\&nrm=iso\&tlng=en

27. Lima DF, Lvy RB, Luiz OC. Recommendations for physical activity and health: consensus, controversies and ambiguities. Rev Panam Salud Publica [Internet]. 2014 [cited 2017 Sept 25];36(3):164-70. Available from: https://scielosp.org/scielo.php?script=sci_arttext\&pid=S102049892014000800004\&lng=en\&nrm=iso\&tlng=en

28. Kim MJ, Son KH, Park HY, Choi DJ, Yoon CH, Lee HY, et al. Association between shift work and obesity among female nurses: Korean Nurses' Survey. BMC Public Health. 2013;13:1204. DOI: http://dx.doi.org/10.1186/1471-2458-13-1204

29. Diaz KM, Howard VJ, Hutto B, Colabianchi N, Vena JE, Safford MM, et al. Patterns of sedentary behavior and mortality in U.S. middle-aged and older adults: a National Cohort Study. Ann Intern Med. 2017;167(7):465-75. DOI: http://dx.doi.org/10.7326/M17-0212

30. Karanikola M, Giannakopoulou M, Mpouzika M, Kaite CP, Tsiaousis GZ, Papathanassoglou EDE. Dysfunctional psychological responses among Intensive Care Unit nurses: a systematic review of the literature. Rev Esc Enferm USP [Internet]. 2015 [cited 2017 Dec 10]; 49(5):847-57. Available from: http://www.scielo.br/scielo.php?script=sci_arttext\&pid=S0080-62342015000500847

Fundação de Amparo à Pesquisa do Estado de São Paulo (FAPESP). Process 2014/10321-1. Conselho Nacional de Desenvolvimento Científico e Tecnológico (CNPq). Process 480667/2013. 